\title{
Katolicki Uniwersytet Powszechny (1940): placówka oświatowo-kulturalna i wydawnicza polskiej społeczności uchodźczej na Węgrzech okresu II wojny światowej
}

Wprowadzenie

$\mathrm{T}^{\mathrm{s}}$ rzema najważniejszymi instytucjami kulturalno-artystycznymi polskiej uchodźczej społeczności przygarniętej po czasowym otwarciu granicy we wrześniu 1939 r. przez Królestwo Węgier ${ }^{1}$ były - zlokalizowane w stołecznym Budapeszcie - Instytut Polski (1938-1944), Świetlica Polska (1939-1942, 1944) oraz Klub Angielski (1940)². Wszystkie pełni-

${ }^{1}$ Ze stosunkowo bogatej literatury przedmiotu na ten temat (skoncentrowanej wszakże niemal wyłącznie na problematyce polityczno-wojskowej oraz kwestiach uchodźczego szkolnictwa) warto wymienić zwłaszcza napisaną po polsku monografię węgierskiego badacza I. Lagzi, Uchodźcy polscy na Węgrzech w latach drugiej wojny światowej, Warszawa 1980.

${ }^{2}$ Ich dość gruntownie zapomnianą, acz bardzo pożyteczną, wcale bogatą oraz interesującą aktywność autor niniejszej pracy starał się przedstawić w kolejnych artykułach: Instytut Polski w Budapeszcie: działalność kulturalno-oświatowa, naukowa i wydawnicza w latach 1939-1944 (złożony do druku w „Annales Academiae Paedagogicae Cracoviensis, Studia ad Bibliothecarum Scientiam Pertinentia", t. VII, pod red. H. Kosętki), Świetlica Polska w Budapeszcie: działalność kulturalno-oświatowa i artystyczna $w$ latach 1939-1944 (złożony do druku w księdze jubileuszowej I. Homoli-Skąpskiej pod red. G. Niecia i U. Orman), Klub Angielski w Budapeszcie (1940): epizod z działalności kulturalno-oświatowej polskiej społeczności uchodźczej na Węgrzech w latach II wojny światowej (złożony do druku w księdze jubileuszowej J. Sowińskiego pod red. H. Kosętki). 
ły w pewnym stopniu (poprzez organizowane publiczne odczyty popularnonaukowe oraz kursy specjalistyczne) także szeroko rozumiane funkcje oświatowe, jakkolwiek właściwie pozostawały poza wypracowanym w porozumieniu ze stosownymi czynnikami węgierskimi oficjalnym systemem uchodźczej oświaty różnych szczebli³. Wszystkie dysponowały także własnymi lokalami, funkcjonowały w logistycznym oparciu na szerszych strukturach (Instytut Polski był od roku 1940 - przynajmniej nominalnie - częścią węgierskiego uniwersytetu im. Pétera Pázmányego, Świetlica Polska stanowiła agendę Amerykańskiego Komitetu Pomocy Polakom, Klub Angielski takąż agendę Angielskiego Komitetu Pomocy Polakom), miały własne kierownictwa oraz (niekiedy nawet etatowy) stały personel.

Inaczej było z egzystującym przede wszystkim na zasadach społecznych, właściwie bez formalnej stałej siedziby, z dość mgliście zarysowanymi strukturami i mało precyzyjnie określonymi celami i programem działania, tzw. Katolickim Uniwersytetem Powszechnym (dalej: KUP). Pierwsza notatka o tej placówce pojawiła się 8 lutego 1940 r. w czołowym organie uchodźstwa polskiego na Węgrzech - budapeszteńskim periodyku „Wieści Polskie”. Pisano, że została właśnie powołana do istnienia nowa instytucja na skutek wspólnych działań Katolickiego Duszpasterstwa nad Uchodźcami Polskimi na terenie Królestwa Węgier (używano też mniej oficjalnej skróconej nazwy Polskie Duszpasterstwo Katolickie; na jego czele stał wówczas biskup polowy Karol Mieczysław Radoński) oraz wspomnianego już Instytutu Polskiego w Budapeszcie (z mgr. Zbigniewem Załęskim jako dyrektorem), która stawia sobie za cel „stworzenie we wszystkich obozach polskich uchodźców na Węgrzech systematycznych kursów popularnego nauczania”" Najwyższą organizacyjną władzę zwierzchnią Katolickiego Uniwersytetu Powszechnego miało stanowić tzw. Kuratorium. W jego składzie znaleźli się: biskup Karol Mieczysław Radoński, przedstawiciel Wojska Polskiego internowanego na terenie Królestwa Węgier gen. bryg. Stefan Dembiński, konsul RP w Budapeszcie Józef Zarański oraz sekretarz generalny ks. kanonik Stefan Pie-

${ }^{3}$ Por. K. Stasierski, Szkolnictwo polskie na Węgrzech w czasie drugiej wojny światowej, Poznań 1969; H. i T. Csorba, Losy młodzieży polskiej na Węgrzech w latach II wojny światowej, Warszawa 1981; F. Budziński, Polskie Gimnazjum i Liceum w Balatonzámardi i Balatonboglár (1939-1944), Lublin 1984; tenże, Szkoły polskie nad Balatonem w okresie II wojny światowej, Warszawa 1988; tenże, Polacy na uczelniach węgierskich w latach II wojny światowej, Kraków 1993 (także: Rzeszów 1993).

4 Powstał Uniwersytet Katolicki, „Wieści Polskie” 1940, nr 13, s. 4. 
truszka. Dodatkowo do spraw merytorycznych związanych z tokiem nauczania stworzono Komitet Naukowy, na czele którego stanął jako prezes dyrektor Instytutu Polskiego Zbigniew Załęski, sekretarzem i zarazem kierownikiem biura Uniwersytetu został Narożański (imię nieustalone), a wiceprezesem Komitetu Kazimierz Tychota ${ }^{5}$. Donoszono też, że „Wykłady obejmować będą następujące przedmioty: religię, literaturę polską, historię, geografię, nauki przyrodnicze, ekonomię, spółdzielczość, higienę, fizykę z chemią, radiotechnikę, socjologię, prawo i naukę o Węgrzech"6, oraz wyrażano nadzieję na współpracę także uczonych węgierskich.

Formalna inauguracja prac nowej placówki, zorganizowana bardzo uroczyście i z dużym rozmachem propagandowym, odbyła się 11 lutego 1940 r. Od razu, poniekąd zgodnie z nazwą, ujawniła się przede wszystkim wyznaniowa, religijno-kościelna orientacja Uniwersytetu:

Inauguracja była poprzedzona nabożeństwem w kościele 00 Paulinów. Na zebranie inauguracyjne w pięknej sali Katolikus Kör przybyli JE ks. Biskup Karol Radoński, konsul Józef Zarański, generał Stefan Dembiński, przedstawiciel poselstwa Rzeczypospolitej p. Szczeniowski, ks. dziekan Miodoński, a z gości węgierskich - prezes Akcji Katolickiej na Węgrzech p. Zsemberg, senator prof. Jenő Czettler, b. prezes parlamentu, prezes Związku Węgrów Legionistów Polskich F. L. Miklósi, sekretarz generalny Węgierskiego Towarzystwa imienia A. Mickiewicza dr Edgar Páloczyi, hr. Bem de Cosban, potomek gen. Bema i inni. Publiczność polska stawiła się bardzo licznie. Na podium stanęły poczty sztandarowe organizacji polskich w Budapeszcie.

Uroczystość zaczęła się odśpiewaniem przez chór akademicki hymnów węgierskiego i polskiego. Zabrał głos ks. biskup Radoński, podkreślając, iż jedną z największych bolączek życia obozowego uchodźców polskich stanowi ich przymusowa bezczynność, odcięcie od pracy, nauki i książki. Wypełnienie tej dotkliwej luki wzięła sobie za cel powstała obecnie placówka, ujmując szerzenie wiedzy w pewien system. Chodzi o to, by uchodźca powróciwszy do kraju miał wzbogacony zasób

${ }^{5}$ Nazwiska najważniejszych członków Komitetu Naukowego zostały podane w publikacji Katolicki Uniwersytet Powszechny na Węgrzech, „Wieści Polskie” 1940, nr 82, s. 4 (ponadto w skład Komitetu wchodzili „, urzędu” autorzy wszystkich odczytów kolportowanych w postaci powielanej przez KUP). Ponieważ zarówno Załęski, jak i Tychota byli pracownikami Instytutu Polskiego w Budapeszcie (Múzeum körút 11), można prawdopodobnie przyjąć, że w tym lokalu mieściło się także wspomniane (nigdy adresowo niepodane do publicznej wiadomości) biuro Uniwersytetu.

${ }^{6}$ Powstał Uniwersytet Katolicki..., s. 4. 
wiedzy i mógł się stać pożytecznym sługą Ojczyzny [...] Z kolei p. Z. Załęski wygłosił odczyt na temat Kościół w walce światopoglądów. Prelegent $\mathrm{w}$ słowach pięknych, nacechowanych głęboką wiarą, podkreślił znaczenie i rolę katolicyzmu jako dźwigni moralnej narodów, przeciwstawiając go materialistycznym wpływom spod znaku swastyki i pięcioramiennej gwiazdy [...] Po przemówieniu tym chór odśpiewał Gaude mater Polonia a następnie zabrał głos mgr Nowosad, który wygłosił odczyt pod tyt. Pierwiastek katolicki w kulturze polskiej. Prelegent scharakteryzował istotę kultury katolickiej, podkreślając jej pierwiastki duchowe, górujące nad materialnymi. Podniosła uroczystość zakończyła się odśpiewaniem przez chór pieśni My chcemy Boga ${ }^{7}$.

Katolicki Uniwersytet Powszechny miał być placówką przede wszystkim organizującą różnotematyczne wykłady i odczyty w poszczególnych uchodźczych obozach cywilnych oraz przeznaczonych dla internowanych żołnierzy. Dlatego też przewidywano powołanie w nich, będących w zamierzeniu podstawą działalności tej instytucji, lokalnych oddziałów KUP. Kierownik danego obozowego oddziału Uniwersytetu miał być powoływany przez wspomniane wyżej Kuratorium na wspólny wniosek komendanta (starszego) obozu oraz... obozowego kapelana. W ten sposób Katolickie Duszpasterstwo zawarowało sobie nader poważny wpływ na pracę inspirowanej przez siebie placówki.

„Wykłady przewiduje się trzy razy w tygodniu po trzy godziny dziennie przed południem oraz dwa razy tygodniowo po dwie godziny popołudniu"8.

W praktyce działalność Katolickiego Uniwersytetu Powszechnego przybrała różne formy; część zajęć miała niejako charakter "centralny” i odbywała się w Budapeszcie, druga zaś część to - mniej lub bardziej sterowane przez naczelne władze KUP - przedsięwzięcia „terenowe” w poszczególnych obozach, przy czym od razu trzeba powiedzieć, że zwłaszcza wiedza o tych ostatnich na skutek braku zachowanych materiałów źródłowych jest bardzo nikła.

7 Placówka, która uchroni uchodźców przed bezczynnościq̨. Inauguracja Katolickiego Uniwersytetu Powszechnego, „Wieści Polskie” 1940, nr 16, s. 4.

${ }^{8}$ Tamże. 


\section{Uroczyste akademie religijno-patriotyczne}

Sczególnie reprezentacyjny charakter miały organizowane „centralnie” przez KUP uroczyste akademie religijno-patriotyczne. Odbyły się dwie. Dnia 12 marca 1940 r., jako pierwsza w ogóle impreza Uniwersytetu, w wynajętej sali Katolikus Kör (Molnár-utca 11) miała miejsce tzw. Akademia Papieska, zorganizowana w pierwszą rocznicę koronacji papieża Piusa XII:

Uroczystość zaszczycił swoją obecnością nuncjusz papieski mgr Angelo Rotta. Ponadto udział w uroczystości wzięli: poseł RP Orłowski, zastępca prymasa Węgier ks. infułat wikariusz generalny dr Mészárós, ks. biskup polowy węgierski dr Hász, ks. biskup Radoński, delegat węgierskiego ministerstwa oświaty Béla Drucker, konsul Zarański, gen. Dembiński, ks. dziekan Miodoński, członkowie Komitetu Obywatelskiego z p. Sławikiem na czele, główny antykwariusz Kossányi Béla, b. prezydent węgierskiego parlamentu sen. prof. Csettler oraz szereg innych wybitnych przedstawicieli społeczeństwa i organizacji polskich w Budapeszcie.

Uroczystość rozpoczęła się odegraniem przez orkiestrę [...] hymnów papieskiego, węgierskiego i polskiego. Ksiądz biskup Karol Radoński powitał w języku francuskim przybyłych dostojników [...] Następnie w języku polskim dostojny mówca podkreślił znaczenie uroczystości ${ }^{9}$.

W przemówieniu biskupa znalazł się także akcent narodowy, gdyż w interpretacji Radońskiego Pius XII jawił się także jako szczególny przyjaciel Polski, szczerze współczujący doświadczonym przez wojnę Polakom ${ }^{10}$.

Główną część akademii wypełnił referat dyrektora Instytutu Polskiego mgr. Zbigniewa Załęskiego zatytułowany „Papiestwo a przełomy dziejowe". Jak można wnioskować z wplecionego w prasowe sprawozdanie z obchodu streszczenia, mówca stanął na stanowisku, że zarówno w dawnych wiekach, jak i całkiem współcześnie „Stolicy Apostolskiej przypadł w udziale zwierzchni nadzór moralny nad wszelką, a więc i państwową działalnością" oraz że stanowi ona podstawowy zwornik całej cywilizacji światowej. Zwłaszcza pontyfikaty papieży od Piusa IX poczynając (nazy-

9 Polacy w hołdzie Ojcu św. Uroczysta Akademia w Budapeszcie, „Wieści Polskie” 1940, nr 29, s. 4.

${ }^{10}$ Kluczowy fragment przemówienia biskupa K. Radońskiego został przytoczony in extenso w publikacji Ojcze święty!, „Wieści Polskie” 1940, nr 29, s. 1. 
wanych wielokrotnie powtarzanym tytułem „Ojców chrześcijaństwa”, co notabene na obszarze zróżnicowanych religijnie Węgrzech, odznaczającym się m.in. znacznym odsetkiem wyznawców protestantyzmu, nie było sformułowaniem najzręczniejszym), uznawał za ukoronowanie dziejów tej instytucji: „Panowania ich są pełne blasku, żywotności i prężności, inicjatywy i odwagi. Równie długiego bezpośredniego wieku potężnych indywidualności nie było dotąd w dynastii papieży"11. W związku z powyższym, powołując się na Quo vadis Sienkiewicza, konkludował, że dalsze zwycięskie trwanie Kościoła katolickiego i papiestwa jest jedynym pewnikiem współczesnych burzliwych dziejów Europy i świata.

O części artystycznej akademii czytamy z kolei: „Wybitny wiolonczelista japoński p. Ekitai Ahn wykonał [...] na wiolonczeli przy akompaniamencie fortepianowym p. St. Urskiego Cantilenę Goltermanna, Przebudzenie wiosny Bacha i Ave Maria Schuberta. Piękną grę artysty przyjęli zebrani hucznymi oklaskami. Mgr W. Nowosad odczytał następnie wzruszający fragment z Quo vadis Sienkiewicza: Męczeństwo św. Piotra"12.

Uroczystości podsumowano wystosowaniem przez zebranych specjalnego rocznicowego adresu hołdowniczego na ręce papieża Piusa XII, w którego patetyczny i archaizowany językowo tekst wpleciono także delikatny i zawoalowany apel w sprawie polskiej o „przywrócenie sprawiedliwości dzieła":

Ojcze święty

Polacy wojskowi i cywilni, synowie Twoi najwierniejsi, dziś uchodźcy z Ojczyzny, w obozach na ziemi węgierskiej zatrzymani, w pierwszą rocznicę dnia, gdy Cię Opatrzność Boska do najwyższego kapłaństwa wyniosła, zanoszą pod przewodnictwem swoich kapłanów u ołtarzy Pańskich najgorętsze modły, prosząc Wszechmocnego, aby zachować raczył Waszą Świątobliwość w opiece Swej i zdrowiu i na prośby Jej sprawił, iżby po zwalczeniu wszelkich przeciwności, przywróconej sprawiedliwości dzieło, pokój Chrystusów, corychlej światu zajaśniał.

Upadając u stóp tronu papieskiego, proszą pokornie o błogosławieństwo apostolskie ${ }^{13}$.

\footnotetext{
${ }^{11}$ Polacy $w$ hołdzie..., s. 4.

12 Tamże.

${ }^{13}$ Cyt. za: Ojcze święty!..., s. 1.0 ile wiadomo, żadnej bezpośredniej reakcji papieża na uroczystość i list hołdowniczy nie było.
} 
Zdecydowanie mniej konfesyjny charakter miała druga akademia zorganizowana przez KUP, a mianowicie uroczysty obchód 149. rocznicy uchwalenia konstytucji w dniu 3 maja 1940 r. Podobnie jak Akademia Papieska, odbyła się w wynajętej sali Katolikus Kör i, tak jak wcześniej, pojawili się na niej najbardziej prominentni przedstawiciele zbiorowości polskiej:

Na uroczystość przybyli poseł RP min. Orłowski z członkami Poselstwa pp. Szczeniowskim, Krajewskim i Zdiarskim, ks. biskup K. Radoński, delegat rządu T. Kunicki, konsul generalny Zarański, major Bastgen, prezes Komitetu Obywatelskiego Sławik, reprezentant węgierskiego min. oświaty Kosányi, przedstawiciele organizacji polskich i inni. Polonia budapeszteńska stawiła się niezwykle tłumnie, szczelnie zapełniając salę ${ }^{14}$.

Centralnymi punktami uroczystości były dwa okolicznościowe przemówienia, pretekstowo jedynie odwołujące się do wydarzeń roku 1791, a przede wszystkim odnoszące się do spraw ściśle współczesnych, przyjęte przez zgromadzonych - jak pisano - ze „łzami w oczach i burzą oklasków", choć z uwagi na sytuację gościnnych Węgier, pozostających przecież w sojuszu z Hitlerem, pełne niedomówień oraz nienazywające nigdzie hitlerowskiego agresora i okupanta po imieniu. Pierwsze z nich, wygłoszone przez posła RP w Budapeszcie Leona Orłowskiego na kanwie dalekiej paraleli historycznej dramatycznych wydarzeń schyłku XVIII w. oraz aktualnej sytuacji roku 1940 i utraty niepodległości przez Polskę, wyrażało przekonanie, że Polacy pokonają wszelkie trudności, jeżeli połączy ich "miłość Polski, godność osobista i narodowa oraz wiara w sprawiedliwość Bożą". Z kolei mowa Tadeusza Kunickiego, delegata rządu RP do spraw uchodźców, koncentrowała się na dwóch obliczach współczesnej Polski („,jedno - wolne, orężne czynem i żelazem na ziemi francuskiej, drugie - męczeńskie a wytrwałe na naszej ziemi") i na specyfice wojennego uchodźstwa na Węgrzech:

My tu, Polacy na Węgrzech, mamy ten wielki przywilej w stosunku do rodaków w innych krajach, że najszybciej i najlepiej możemy odczuć bicie serca naszego kraju, że hartować możemy naszego ducha na przykładzie tych, którzy w Polsce trwają - na przykładzie olbrzymiej większości narodu. I chociaż równie szybciej dochodzą do nas wieści straszne

${ }^{14}$ Jak uczciliśmy rocznicę 3 Maja, „Wieści Polskie” 1940, nr 51, s. 4. 
i smutne, to jednaką wywołują one świadomość, że zdecydowanie i wytrwałość są warunkami koniecznymi, aby serca nasze poprzez najcięższe doświadczenie przygotować do wielkiej radości zwycięstwa ${ }^{15}$.

Całość zamknęła część artystyczna, o której czytamy w sprawozdaniu prasowym: „Młody utalentowany śpiewak (bas) M. Nowakowski przy akompaniamencie prof. M. Zawadzkiego odśpiewał Bogurodzice - kompozycję prof. Zawadzkiego oraz Wodza Maklakiewicza, po czym dyr. S. Ligoń recytował Mickiewicza - Piosenkę żołnierskq̨ i Lenartowicza fragment z Bitwy Racławickiej. Na zakończenie programu orkiestra wykonała wiązankę pieśni polskich"16.

\section{Popularne wykłady, odczyły i gawędy}

Dodstawową i najważniejszą formą pracy Uniwersytetu były organizowane „w terenie” (w poszczególnych rozproszonych obozach uchodźczych) popularne wykłady, odczyty i gawędy, o których - jak już wspomniano wyżej - dysponujemy jednakowoż dziś najmniejszą wiedzą. Szczątkowe informacje o nich rozproszone na łamach „Wieści Polskich” tchną urzędowym optymizmem. Dowiadujemy się np., że już w kwietniu 1940 r. egzystowało 58 energicznie pracujących oddziałów KUP, że wykłady cieszyły się wszędzie znacznym powodzeniem, a „Komitet naukowy [...] czyniąc zadość życzeniom z terenu rozszerzył program [...] wprowadzając dział rolniczy omawiający zagadnienia komasacji, melioracji i regulacji gruntów" ${ }^{\prime 17}$. Nie ma powodu, aby całkowicie negować te doniesienia, ale - jak się zdaje - w praktyce sytuacja nie była aż tak beztrosko optymistyczna.

Wykłady „w terenie” miały postać dwojaką. Po części były przygotowywane „centralnie” przez Komitet Naukowy w postaci - prawdopodobnie - dziś zupełnie niezachowanych materiałów powielanych, gotowych po prostu do odczytania w poszczególnych oddziałach KUP, po części opierały się na bardzo zróżnicowanych w swoim potencjale lokalnych siłach i możliwościach poszczególnych obozów. Ze sporządzanych na bieżąco

\footnotetext{
15 Tamże.

16 Tamże.

17 Katolicki Uniwersytet Powszechny rozszerza swoja działalność, „Wieści Polskie” 1940, nr 42, s. 4.
} 
(a wydanych dopiero w 1958 r.) zapisków Juliana Kurdybowicza, zawodowego podoficera o pewnych ambicjach i umiejętnościach artystycznych oraz pamiętnikarza chętnie i mocno angażującego się w kulturalne życie uchodźstwa, wyłania się jednakowoż znacznie mniej krzepiący obraz egzystencji terenowych oddziałów KUP. Zapiski Kurdybowicza ujawniają, że przynajmniej niektóre z oddziałów KUP były bytami raczej wirtualnymi i istniejącymi bardziej w sprawozdaniach dla władz niż w rzeczywistości, służącymi jedynie zaspokajaniu potrzeby prestiżu i (jakże iluzorycznych) formalnych tytułów oraz godności niektórych obozowych „dygnitarzy". Przebywający początkowo w obozie dla internowanych żołnierzy w miejscowości Horce-Ozsöröny notował m.in. z satysfakcją:

Od dwóch miesięcy, przed południem, odbywają się u nas wykłady uniwersytetu katolickiego. Przyjmowane początkowo niechętnie, teraz cieszą się dużą frekwencją. Dają one dużą korzyść - uczą i zmniejszają monotonię pobytu. Wykłady są o tyle ciekawe, że mówią o wszystkim. Nasz bernardyn [kapelan obozowy, a zarazem wykładowca KUP] to człowiek światowy, elokwentny, przez kilka lat był misjonarzem w dalekich krajach. Opowiada barwnie i bardzo ciekawie o zwyczajach i obyczajach w odległych krajach ${ }^{18}$.

Gdy jednak obóz zlikwidowano, a żołnierzy (w tym Kurdybowicza) przeniesiono do innego obozu w Jolsvà, gdzie również działał oddział Uniwersytetu, w notatkach na ten temat pojawił się ton rozczarowania i sarkazmu:

Każde przedsięwzięcie obliczone jest przede wszystkim na efekt. $\mathrm{W}$ wielu wypadkach tabliczka z pięknie wykonanym napisem to parawan, poza którym nic się nie dzieje. Ot, po prostu firma, zręcznie maskująca lenistwo.

Przykładem jest „uniwersytet katolicki”. W poprzednim obozie wykłady rozpoczęły się przed trzema miesiącami i trzeba przyznać, powiększyły nieco horyzont umysłowy naszych żołnierzyków. W obecnym obozie odbyło się uroczyste otwarcie przed dwoma tygodniami; było kilka przemówień i na tym koniec. Nic więcej się nie robi. Charakterystyczne wykonanie rozkazu: zaczęło się i pauza...

${ }^{18} \mathrm{~J}$. Kurdybowicz, Tułaczym szlakiem. Kartki z pamiętnika żołnierza, wstęp i oprac. H. Csorba, Wrocław 1958, s. 148. 
Przepraszam! Dziś rano jacyś panowie szukali specjalisty od sztuki pięknego pisania - na pewno sporządzą jeszcze jedną tabliczkę firmową... ${ }^{19}$.

Akcja rzeczywistych bądź, jak zdaje się wynikać ze wspomnień Kurdybowicza, niekiedy jedynie „wirtualnych” wykładów KUP „w terenie” została ostatecznie decyzją kierownictwa placówki zakończona na przełomie czerwca i lipca $1940 \mathrm{r}^{20}$

\section{Wyi̇sze Studium Społeczne KUP}

Szzególną „mutacją” owych wykładów publicznych - tym razem orgaOnizowanych jedynie „centralnie” i odbywających się wyłącznie w stołecznym Budapeszcie, a poza tym adresowanych już głównie do wyselekcjonowanego, bardziej wykształconego oraz inteligenckiego odbiorcy - było tzw. Wyższe Studium Społeczne KUP. Uruchomiono je w kwietniu 1940 r. w wyniku współpracy kierownictwa Uniwersytetu z węgierską Akcją Katolicką oraz międzynarodową organizacją studentów katolickich „Pax Romana”. Zapowiadano, że Studium - stawiające sobie za cel wytworzenie „ogniska twórczej katolickiej myśli polskiej emigracji” ${ }^{21}$ - obejmie „wykłady dyskusyjne z szeregu dziedzin, jak filozofia, religia, ekonomia, socjologia, historia, nauka o Węgrzech, teoria prawa itp."22 Po ich ustnym wygłoszeniu w Budapeszcie miały być utrwalane w formie skryptowej i przesyłane do zainteresowanych inteligenckich odbiorców w poszczególnych obozach. Faktycznie odbyły się tylko trzy - znane dziś jedynie z anonsów prasowych - wykłady Wyższego Studium Społecznego:

- Emiliana Ostachowskiego „Na nowym szlaku dziejowym” (29 kwietnia 1940 r. w sali Collegium Emericana, Bástya-utca 11) ${ }^{23}$,

- Zbigniewa Załęskiego „Człowiek w świetle filozofii” (14 maja 1940 r. w tej samej sali Collegium Emericana) ${ }^{24}$,

\footnotetext{
19 Tamże, s. 154-155.

${ }^{20}$ Informuje o tym wzmianka w artykule Nowe wydawnictwo polskie na Węgrzech, „Wieści Polskie” 1940, nr 60, s. 4.

${ }^{21}$ Komitet Naukowy Katolickiego Uniwersytetu Powszechnego, „Wieści Polskie” 1940, nr 46, s. 4 .

${ }^{22}$ Katolicki Uniwersytet Powszechny rozszerza..., s. 4.

${ }^{23}$ Komitet Naukowy..., s. 4.

${ }^{24}$ Wykłady Studium Społecznego, „Wieści Polskie” 1940, nr 53, s. 4.
} 
- Emiliana Ostachowskiego „Istota publicznego wychowania chrześcijańskiego" (28 maja 1940 r. w sali Instytutu Polskiego, Múzeum körút 11$)^{25}$.

Tytuły prelekcji zdają się wskazywać, że ze wszystkich przedsięwzięć KUP były to prawdopodobnie odczyty najbardziej programowo i merytorycznie współbieżne z konfesyjno-kościelną generalną orientacją placówki.

\section{Działalność wydawnicza}

O sobną kartą aktywności Katolickiego Uniwersytetu Powszechnego była jego działalność wydawnicza. Przeszła ona przez dwa etapy, oba szczególnie trudne do zbadania z racji właściwie całkowitego niezachowania się podstawowych materiałów źródłowych, stąd konieczne jest oparcie się jedynie na nie zawsze precyzyjnych i niejasnych w niektórych szczegółach informacjach „z drugiej ręki”. Pierwszy etap przypadł na okres od lutego do połowy czerwca 1940 r. Polegał na wydawaniu przez centralę KUP powielanych - prawdopodobnie za pomocą sprzętu, którym dysponował Instytut Polski - tekstów wykładów i referatów przesyłanych lokalnym oddziałom Uniwersytetu do pomocniczego wykorzystania, lub wręcz do odczytania in extenso. Nie zachowało się z nich nic, nie znamy ani autorów, ani tytułów poszczególnych wystąpien ${ }^{26}$. W jedynej sumarycznej informacji prasowej na ten temat czytamy:

Uniwersytet dostarczał materiałów do pogłębienia myśli, do kształcenia się, do uzupełnienia już nabytych wiadomości w najrozmaitszych gałęziach wiedzy. Wydano cały szereg systematycznych kursów popularnonaukowych z zakresu religii, nauki o Węgrzech, literatury polskiej, historii, geografii, przyrody, spółdzielczości, prawa, fizyki, chemii, socjologii, higieny i ekonomii. Kursy opracowane w formie wykładów przez specjalistów odbijano na cyklostylu i wysyłano do wszystkich obozów. Tygodniowo przygotowywano 7-9 referatów. Do 15 czerwca br. wysłano ogółem 87 referatów ${ }^{27}$.

\footnotetext{
${ }^{25}$ Wykład w Instytucie Polskim, „Wieści Polskie” 1940, nr 60, s. 4.

${ }^{26}$ Nie notuje ich także skądinąd bardzo skrupulatna i wciąż użyteczna praca: H. Csorby i I. Michalak, Bibliografia poloniców węgierskich 1939-1945, „Biuletyn Instytutu Bibliograficznego", t. VI: 1958, nr 3.

${ }_{27}$ Katolicki Uniwersytet Powszechny na Węgrzech..., s. 4.
} 
Drugi etap, już po zamknięciu cyklu wykładów powszechnych, rozpoczął się w lipcu 1940 r. i polegał na uruchomieniu - zamiast wygłaszanych i rozsyłanych prelekcji - regularnego, powielanego periodyku KUP. W założeniu tygodnik, redagowany przez Komitet Naukowy, był przeznaczony do wykorzystywania w pracy kulturalno-oświatowej poszczególnych obozowych świetlic. Najprawdopodobniej żaden egzemplarz tego pisemka nie zachował się, niestety, do naszych czasów. Jak się zdaje, jego przechowywania i archiwizowania zaniedbano, podobnie jak i wielu innych periodyków węgierskiego uchodźstwa, jeszcze w czasie wojny. Stąd informacje, którymi na ten temat dysponujemy, są bardzo niepełne. Rozbieżności dotyczą nawet brzmienia tytułu i czasu ukazywania się. Zdaniem rzetelnego pamiętnikarza i wiarygodnego faktografa życia kulturalno-intelektualnego uchodźstwa na Węgrzech, dziennikarza Zdzisława Antoniewicza, tytuł periodyku brzmiał „Katolicki Uniwersytet Powszechny. Materiały Świetlicowe", a jego pierwszy numer miał się ukazać 25 maja $1940 \mathrm{r}^{28}$ Datę tę podaje także - nie na podstawie autopsji - bibliografia wojennych poloniców węgierskich Heleny Csorby oraz Ireny Michalak, opowiadając się jednak za tytułem w wersji „Materiały Świetlicowe. Katolicki Uniwersytet Powszechny"29. Podważa ją Danuta Jakubiec ${ }^{30}$, przypominająca z kolei, że według sporządzanej na bieżąco w czasie wojny - choć nieco po amatorsku - bibliografii Aleksandra Króla pierwszy numer pisemka ukazał się 25 czerwca $1940 \mathrm{r}^{31}$ Ta ostatnia informacja wydaje się najbliższa prawdy, gdyż pierwsze prasowe omówienie jeszcze „gorącego” zeszytu inauguracyjnego „Materiałów Świetlicowych” (taką krótką wersję tytułu podano) odnajdujemy w „Wieściach Polskich” z 2 lipca 1940 r. „Wieści Polskie” zamieszczały zresztą mniej lub bardziej obszerne - czasem nawet ilustrowane dłuższymi cytatami źródłowymi z publikacji uznanych za najważniejsze - omówienia niemal wszystkich kolejnych zeszytów „Materiałów Świetlicowych” KUP, tak więc w przybliżeniu można sobie na tej podstawie wyrobić pogląd o ich zawartości.

28 Z. Antoniewicz, Uchodźcza prasa na Węgrzech (1939-1944), „Rocznik Historii Czasopiśmiennictwa Polskiego" 1975, z. 2-3, s. 301.

${ }^{29}$ H. Csorba, I. Michalak, dz. cyt., s. 116, poz. 235.

30 D. Jakubiec, Wydawnictwa periodyczne uchodźców polskich na Węgrzech $w$ latach 1939-1944, „Zeszyty Prasoznawcze” 1971, nr 3, s. 36.

31 Bibliografia wydawnictw polskich na Węgrzech (od 18 września 1939 do 1 grudnia 1941), „Rocznik Polski. Kalendarz Polaka na Węgrzech na rok 1942”, Budapeszt [1941], s. $241-245$. 
W słowie wstępnym do czytelników zeszytu pierwszego redakcja „Materiałów” pisała, czyniąc m.in. przejrzystą aluzję do świeżej, a dla Polaków szczególnie bolesnej, klęski Francji w wojnie z Niemcami:

Po zamknięciu wiosennych wykładów powszechnych, zeszytem niniejszym rozpoczynamy nowy etap pracy. Będzie on różny w metodzie i treści.

Teraz w okresie letnim, kiedy wielu z Was pomaga gościnnym gospodarzom w ich pracach gospodarskich, teraz kiedy strapione oblicza nasze jeszcze bardziej spochmurniały, trzeba by myśl nasza zwróciła się do prawd wiecznych i do wielkich a kojących skarbów naszej poezji. Trzeba również poznawać bliżej skarby kultury duchowej i materialnej narodu węgierskiego, z którego życzliwej gościnności już tyle miesięcy korzystamy, a nie wiadomo, ile przyjdzie nam jeszcze korzystać.

Weźcie ten zeszyt do ręki i niech dla tych z Was, których natura obdarzyła zdolnościami wychowawczymi, będzie drogowskazem i pomocą dla innych z Was, którzy w samotności zagłębią się w lekturę rozważań naszych, niech będzie kojącym wytchnieniem i stanie się drogą poznania i duszy pogłębienia ${ }^{32}$.

Program i planowana zawartość periodyku zostały więc zarysowane skrótowo, ale dość jasno: materiały popularnonaukowe i samokształceniowe dotyczące „prawd wiecznych”, a także hungarica oraz wybrane i uznane przez redakcję za wybitne utwory literatury, zwłaszcza poezji narodowej. W sumie w roku 1940 staraniem i sumptem Katolickiego Uniwersytetu Powszechnego ukazało się prawdopodobnie osiem zeszytów (numerów) „Materiałów Świetlicowych”. Pierwszy, jak wspomniano wyżej, zapewne u schyłku czerwca, drugi, trzeci i czwarty w lipcu, piąty, szósty i zapewne siódmy w sierpniu, wreszcie ósmy w początkach września. Trzy pierwsze zostały bardzo dokładnie omówione w „Wieściach Polskich" ${ }^{33}$, o czwartym, piątym i szóstym zamieszczono tamże zwięzłe informacje na temat ich zawartości ${ }^{34}$, o siódmym i ósmym nie wiemy natomiast dosłownie nic. Poniższa tabela przedstawia zrekonstruowaną zawartość periodyku KUP.

32 Cyt. za: Nowe wydawnictwo polskie..., s. 4.

33 Tamże, s. 4 (dot. zesz. 1); O hart ducha!, „Wieści Polskie” 1940, nr 80, s. 4 (dot. zesz. 2); Potęga Opatrzności, „Wieści Polskie” 1940, nr 83 (dot. zesz. 3), s. 4.

34 „Materiałów Świetlicowych” zeszyt 4-ty, „Wieści Polskie” 1940, nr 85, s. 4; 5 zeszyt „Materiałów Świetlicowych”, „Wieści Polskie” 1940, nr 89, s. 4; Na 15 sierpnia, „Wieści Polskie" 1940, nr 93, s. 4. 
Tabela. Zawartość periodyku „Materiały Świetlicowe. Katolicki Uniwersytet Powszechny" (1940)

\begin{tabular}{|c|c|c|}
\hline $\begin{array}{l}\text { Zeszyt „Materiałów } \\
\text { Świetlicowych” }\end{array}$ & Artykuły & $\begin{array}{l}\text { Utwory literackie } \\
\text { i teksty źródłowe }\end{array}$ \\
\hline 1 (czerwiec 1940) & $\begin{array}{l}\text { Franciszek Sawicki: Założe- } \\
\text { nia filozoficzne katolickiej myśli } \\
\text { społecznej, } \\
\text { Zbigniew Załęski: Kryzys czło- } \\
\text { wieka }\end{array}$ & $\begin{array}{l}\text { Adam Mickiewicz: Rozmowa } \\
\text { wieczorna, } \\
\text { Węgierskie credo }\end{array}$ \\
\hline 2 (lipiec 1940) & $\begin{array}{l}\text { Zbigniew Załęski: } O \text { hart ducha, } \\
\text { K.[azimierz] Tych.[ota]: Węgry } \\
\text { w opisie i cyfrach }\end{array}$ & $\begin{array}{l}\text { Jan Kasprowicz: Błogosławieni, } \\
\text { Deotyma: Wisła rzek polskich, } \\
\text { Testament Żółkiewskiego, } \\
\text { August Cieszkowski: Ojcze nasz } \\
\text { (fragmenty) }\end{array}$ \\
\hline $\begin{array}{l}3 \text { (lipiec 1940), } \\
\text { edycja specjalna } \\
\text { poświęcona „wie- } \\
\text { rze i jej wartościom } \\
\text { w życiu jednostki } \\
\text { i społeczeństwa” }\end{array}$ & $\begin{array}{l}\text { Piotr Wilk-Witosławski: Potęga } \\
\text { Opatrzności, } \\
\text { Zbigniew Załęski: Święci pionie- } \\
\text { rzy kultury węgierskiej }\end{array}$ & $\begin{array}{l}\text { Adam Mickiewicz: Księgi piel- } \\
\text { grzymstwa polskiego } \\
\text { (fragmenty), } \\
\text { Jan Kasprowicz: Trzeba nam } \\
\text { wiary, } \\
\text { Kornel Ujejski: Maraton (frag- } \\
\text { menty) }\end{array}$ \\
\hline 4 (lipiec 1940) & $\begin{array}{l}\text { K.[azimierz] Tych.[ota]: Węgry } \\
\text { w opisie i cyfrach (ludność), } \\
\text { Zbigniew Załęski: Gotowość do } \\
\text { poświęceń, } \\
\text { Szlakami złudzeń }\end{array}$ & $\begin{array}{l}\text { Zygmunt Krasiński: Irydion } \\
\text { (fragmenty), } \\
\text { Piotr Skarga: Kazanie o miłości } \\
\text { ku ojczyźnie, } \\
\text { Jan Kasprowicz: Z chałupy } \\
\text { (fragmenty), } \\
\text { Wincenty Pol: Proroctwo kapła- } \\
\text { na polskiego, } \\
\text { Jan Mahoń: Minął poranek } \\
\text { (pieśń) }\end{array}$ \\
\hline $\begin{array}{l}5 \text { (sierpień 1940), } \\
\text { edycja specjal- } \\
\text { na w 76. rocznicę } \\
\text { śmierci Romualda } \\
\text { Traugutta }\end{array}$ & $\begin{array}{l}\text { Józef Jarzębowski: Traugutt } \\
\text { twórca ostatniego sojuszu pol- } \\
\text { sko-węgierskiego, } \\
\text { Zbigniew Załęski: [sylwetka Ro- } \\
\text { mualda Traugutta] }\end{array}$ & $\begin{array}{l}\text { Juliusz Słowacki: Ksiądz Marek } \\
\text { (fragmenty), } \\
\text { Władysław Ludwik Anczyc: } \\
\text { Emisariusz, } \\
\text { Władysław Stanisław Reymont: } \\
\text { Pęknięty dzwon, } \\
\text { Jan Mahoń: Przysięga (pieśń) }\end{array}$ \\
\hline
\end{tabular}


Tabela. Zawartość periodyku „Materiały Świetlicowe. Katolicki Uniwersytet Powszechny" (1940) (ciąg dalszy)

\begin{tabular}{|l|l|l|}
\hline $\begin{array}{l}\text { Zeszyt „Materiałów } \\
\text { Świetlicowych” }\end{array}$ & \multicolumn{1}{|c|}{ Artykuły } & \multicolumn{1}{|c|}{$\begin{array}{c}\text { Utwory literackie } \\
\text { i teksty źródłowe }\end{array}$} \\
\hline $\begin{array}{l}\text { 6 (sierpień 1940), } \\
\text { edycja specjalna } \\
\text { w 20. rocznicę bitwy } \\
\text { warszawskiej } \\
15 \text { VIII 1920 r. }\end{array}$ & $\begin{array}{l}\text { Zbigniew Załęski: Rocznica, } \\
\text { rupki, } \\
\text { K.[azimierz] Tych.[ota]: Prze- } \\
\text { bacz nam Panie, } \\
\text { Wanda Dziembowska: Bitwa } \\
\text { warszawska, } \\
\text { Węgry a wojna polsko-bolsze- } \\
\text { wicka }\end{array}$ & Bogurodzica \\
\hline 7 (sierpień (?) 1940) & brak informacji & brak informacji \\
\hline 8 (wrzesień 1940) & brak informacji & brak informacji \\
\hline
\end{tabular}

Źródło: opracowanie własne.

„Materiały Świetlicowe” specjalizowały się więc, jak widać z powyższego zestawienia, przede wszystkim w prezentowanej w sposób możliwie popularny problematyce filozoficzno-religijnej i etycznej wyraźnie inspirowanej doktryną katolicką. Wnosiły także swój wkład w szerzenie wśród uchodźstwa szeroko pojętej wiedzy o Węgrzech, ze szczególnym uwzględnieniem miejscowych tradycji katolickich oraz dziejowych związków węgiersko-polskich ${ }^{35}$. Wybierane przez redakcję teksty literackie świadczyły z kolei o dość tradycjonalistycznych i wyraźnie zabarwionych nieco „szkolarską" dydaktyką patriotyczną upodobaniach zespołu „Materiałów”, niekiedy próbującego rewaloryzować także utwory już w 1940 r. jaskrawo anachroniczne i o nikłej wartości artystycznej (Deotyma). Trzeba wszakże pamiętać, że redakcja dysponowała dość skromnymi zasobami uchodźczych księgozbiorów, a tym samym ograniczonymi możliwościami wyboru. Zwracał uwagę także fakt, iż absolutna większość

35 Zauważmy na marginesie, że ogłoszony w numerze 5 „Materiałów Świetlicowych” szkic J. Jarzębowskiego o „węgierskiej” polityce R. Traugutta (drukowany przed wojną w „Prosto z mostu” oraz w osobnej broszurze-nadbitce pt. Wegierska polityka Traugutta (na podstawie znanych i nieznanych dokumentów), Warszawa 1939) został nieco później przetłumaczony na język węgierski i w listopadzie 1943 r. ogłoszony drukiem nakładem Instytutu Polskiego (J. Jarzębowski, Az utolsó magyar-lengyel szövetseg, Fortidotta: Bérendi Sándor, Budapest 1943). 
najaktywniejszych autorów pisemka rekrutowała się z grona pracowników Instytutu Polskiego w Budapeszcie (Zbigniew Załęski, Kazimierz Tychota, Wanda Dziembowska), gdzie - przypomnijmy - pisemko redagowano i powielano oraz gdzie najprawdopodobniej mieściło się też biuro KUP. Nie będzie więc raczej nadużyciem uznanie istnienia swoistej „unii personalnej" między znaczną częścią - skromnego zresztą personelu Instytutu Polskiego, redakcją „Materiałów Świetlicowych” i najbardziej aktywnym jądrem Komitetu Naukowego KUP.

W początkach września 1940 r., w związku z nieznanymi już dzisiaj okolicznościami, doszło do rozdźwięku między Katolickim Duszpasterstwem Polskim (będącym, jak wcześniej wspomniano, instytucją współsprawczą Katolickiego Uniwersytetu Powszechnego) a redakcją „Materiałów Świetlicowych", będących wydawnictwem KUP. Gdy ukazał się ich zeszyt 8 - o zawartości którego, niestety, nie wiadomo dziś absolutnie nic - ówczesny (kolejny po biskupie Radońskim) kierownik Duszpasterstwa o. Piotr Wilk-Witosławski zareagował na łamach „Wieści Polskich” nerwowym komunikatem urzędowym, ujawniającym przy okazji, że pisemko podlegało nie tylko cenzurze węgierskiej, ale i dodatkowo polskiej wewnętrznej cenzurze kościelnej:

Wyjaśnienie

Kierownictwo Katolickiego Duszpasterstwa Polskiego stwierdza, że 8 zeszyt „Materiałów Świetlicowych” Katolickiego Uniwersytetu Powszechnego nie był mu oddany do cenzury.

Budapeszt, 5 września 1940

Kierownik Katolickiego Duszpasterstwa Polskiego

o. Piotr Wilk Witosławski ${ }^{36}$.

Epizod ten, dziś niejasny i z powodu niezachowania się żadnego egzemplarza zeszytu raczej już niemożliwy do wyjaśnienia, jest zarazem ostatnim momentem w dziejach Katolickiego Uniwersytetu Powszechnego. Najprawdopodobniej we wrześniu 1940 r., bez wyjaśnień ani oficjalnych komunikatów, po ośmiu miesiącach istnienia Uniwersytet po prostu zaprzestał dalszej działalności w jakiejkolwiek formie zarówno w Budapeszcie, jak i w poszczególnych polskich obozach. Przyczyny dość nagłej likwidacji placówki nie są znane. Jak się jednak zdaje, wchodziły tu w grę

${ }^{36}$ Wyjaśnienie, „Wieści Polskie” 1940, nr 104, s. 4. 
przede wszystkim względy finansowe. Zdzisław Antoniewicz wspominał po latach, że powodem zakończenia działalności KUP był „brak funduszy na opłacanie wykładowców"37. Być może nie jest to wyjaśnienie całkowicie satysfakcjonujące. Wszakże wykładów publicznych KUP zaniechano już w czerwcu 1940 r., a Uniwersytet - poprzez swoje „Materiały Świetlicowe" - egzystował jeszcze do września 1940 r. Niemniej kłopoty finansowe należy poważnie wziąć pod uwagę, ewentualnie rozszerzając je także o niemożność dalszego pokrywania kosztów przygotowania i powielania „Materiałów”.

\section{Podsumowanie}

We wrześniu 1940 r. Katolicki Uniwersytet Powszechny zakończył więc swoją kilkumiesięczną działalność i na zawsze zniknął z uprzednio bardzo aktywnie przez siebie zagospodarowywanego obszaru polskiego życia intelektualnego na węgierskim wychodźstwie. Pomysły i inicjatywy dotyczące pożytecznej organizacji czasu wolnego „Lengyelów"38 zrodzone w kręgu KUP okazały się wszakże trwalsze niż sam Uniwersytet. Przede wszystkim dotyczyło to podstawowej idei popularnych odczytów publicznych na różne tematy, co zostało podchwycone i kontynuowane - już niekoniecznie w znamiennej dla KUP otoczce kościelno-konfesyjnej - także przez inne centra kulturalno-artystyczne i oświatowe diaspory węgierskiej. Pierwszy odczyt w Świetlicy Polskiej odbył się 13 marca 1940 r., a w Klubie Angielskim 19 kwietnia 1940 r. Swoistym nawiązaniem do tradycji, adresowanego głównie do inteligenckiej elity uchodźczej, Wyższego Studium Społecznego KUP stało się uruchomienie - także, niestety, efemerycznych - tzw. Kursów Wyższych pod auspicjami Komisji Kulturalno-Oświatowej Komitetu Obywatelskiego do Spraw Opieki nad Polskimi Uchodźcami na Węgrzech, odbywających się od stycznia do marca $1941 \mathrm{r}$. W nieco skorygowanej formule - i wielokrotnie potem zmieniające tytuł, instytucję sprawczą oraz wydawcę - przetrwały także skromne powielaczowe „Materiały Świetlicowe". W ostatnim stadium swoich dziejów przekształciły się w poważ-

37 Z. Antoniewicz, dz. cyt., s. 301.

38 Słowo „Lengyel” (w j. węg. „Polak”) często było używane w środowisku uchodźczym na Węgrzech jako rodzaj po części żartobliwej samoidentyfikacji i odróżniania się od innych zbiorowości polskiej wojennej diaspory. 
ny drukowany „Tygodnik Polski. Materiały Obozowe” (25 lipca 1943-12 marca 1944) ${ }^{39}$. Oddziaływanie Katolickiego Uniwersytetu Powszechnego na diasporę polską na Węgrzech, w sensie - co ciekawe - przede wszystkim inspiracyjno-organizacyjnym, a w o wiele mniejszym stopniu światopoglądowym czy wyznaniowym, było zatem o wiele dłuższe i silniejsze niż faktyczna ośmiomiesięczna egzystencja tej placówki.

\section{Katolicki Uniwersytet Powszechny [Catholic Common \\ University] (1940): cultural, educational and publishing institution for refugees in Hungary during the Second World War \\ Abstract}

During the Second World War in Hungary there were four important cultural and artistic institutions popular among Polish refugees: Instytut Polski, Świetlica Polska, Klub Angielski and Katolicki Uniwersytet Powszechny [Catholic Common University]. The last institution provided several activities' like religious and patriotic ceremonies, lectures and readings organized in refugee camps. Wyższe Studium Społeczne addressed a lot of events to educated recipients. Additionally the university dealt with publishing activities which included publishing of many works and documents which were later sent to local departments. Later it focused on publishing "Materiały Świetlicowe. Katolicki Uniwersytet Powszechny", eight issues this magazine were published and after that Katolicki Uniwersytet Powszechny [Catholic Common University] was closed down. It was probably connected with financial problems of this institution.

39 Por. H. Csorba, I. Michalak, dz. cyt., s. 116, poz. 235; s. 117, s. 245; D. Jakubiec, dz. cyt., s. 36; Z. Antoniewicz, dz. cyt., s. 301-303. 